\title{
Compartmentalised expression of meprin in small intestinal mucosa: enhanced expression in lamina propria in coeliac disease
}

\author{
Daniel Lottaz ${ }^{1, a, *}$, Caroline Buri²,a, Giovanni \\ Monteleone $^{3}$, Sandra Rösmann', Thomas T. \\ MacDonald $^{4}$, Ian R. Sanderson ${ }^{5}$ and Erwin E. \\ Sterchi1 \\ ${ }^{1}$ Institute of Biochemistry and Molecular Medicine, \\ University of Bern, CH-3012 Bern, Switzerland \\ ${ }^{2}$ University Hospital of Clinical Psychiatry, University of \\ Bern, CH-3010 Bern, Switzerland \\ ${ }^{3}$ Department of Internal Medicine, University Tor \\ Vergata, I-0133 Rome, Italy \\ ${ }^{4}$ Institute of Cell and Molecular Science, Barts and the \\ London School of Medicine and Dentistry, London E1 \\ 2AT, UK \\ ${ }^{5}$ Research Centre for Gastroenterology, Institute of Cell \\ and Molecular Science, Barts and the London, Queen \\ Mary School of Medicine and Dentistry, London E1 \\ 2AD, UK \\ ${ }^{*}$ Corresponding author \\ e-mail: daniel.lottaz@mci.unibe.ch
}

\begin{abstract}
Epithelial cells in the human small intestine express meprin, an astacin-like metalloprotease, which accumulates normally at the brush border membrane and in the gut lumen. Therefore, meprin is targeted towards luminal components. In coeliac disease patients, peptides from ingested cereals trigger mucosal inflammation in the small intestine, disrupting epithelial cell differentiation and function. Using in situ hybridisation on duodenal tissue sections, we observed a marked shift of meprin mRNA expression from epithelial cells, the predominant expression site in normal mucosa, to lamina propria leukocytes in coeliac disease. Meprin thereby gains access to the substrate repertoire present beneath the epithelium.
\end{abstract}

Keywords: endopeptidases; enteritis; enterocytes; gluten; inflammation; leukocytes.

In coeliac disease, inflammatory reaction in the mucosa is triggered in susceptible individuals by gliadin-derived peptides, which activate lamina propria and intraepithelial T-cells, thereby promoting tissue damage consisting of villus atrophy and crypt hyperplasia (Sollid, 2002; Shan et al., 2002, 2005; Koning, 2005). Proteases, in particular matrix metalloproteases (MMPs), are believed to play a

\footnotetext{
a These authors contributed equally to this work
}

major role in these processes. Indeed, enhanced expression of MMP-1 and MMP-3 has been documented in the intestinal mucosa of coeliac disease patients (Daum et al., 1999). In addition, activation of lamina propria Tcells in organ cultures of human foetal gut explants leads to increased production of pro-inflammatory cytokines from T-helper 1 (Th1) cells and upregulation of MMP-3 and MMP-12, which causes morphological changes that mimic those observed in coeliac disease. Addition of synthetic MMP inhibitors prevented deterioration of the mucosa in this system (Pender et al., 1997; Monteleone et al., 1999; Salmela et al., 2001). We hypothesised that expression of meprin, an astacin-like metalloprotease that is constitutively expressed by intestinal epithelial cells and thus provides continuous proteolytic activity directed towards the gut lumen (Sterchi et al., 1988b; Dumermuth et al., 1991; Lottaz et al., 1999a), might be altered in coeliac disease.

Meprin (EC 3.4.24.18) is distinct from MMPs in terms of structure and multi-domain organisation (Dumermuth et al., 1991). The protease consists of homo- and heterooligomeric complexes of two homologous isoforms, meprin $\alpha$ and meprin $\beta$, which accumulate at the brush border membrane of villus enterocytes and are partially secreted into the gut lumen. Biosynthesis of meprin has been studied in intestinal biopsies in organ culture (Sterchi et al., 1988a) and in transfected mammalian cells (Grünberg et al., 1993; Eldering et al., 1997; Pischitzis et al., 1999). Different forms were observed, generated by posttranslational modifications and proteolytic processing along the secretory pathway. Both meprin $\alpha$ and meprin $\beta$ are synthesised as glycosylated transmembrane proteins, and smaller soluble forms are generated through proteolytic processing steps. The 100-kDa precursor form of meprin $\alpha$ is retained in the endoplasmic reticulum, where a proteolytic processing step leads to the removal of its membrane anchor. This soluble 80-85$\mathrm{kDa}$ form, which still contains carbohydrate moieties that are sensitive to digestion by endoglycosidase $\mathrm{H}$, is subsequently transported through the Golgi complex, acquiring complex glycosylation, and is finally secreted as the mature soluble $90-95-\mathrm{kDa}$ protein. Meprin $\beta$ is transported to the cell surface as a transmembrane protein (100-105 kDa), but may also be partially shed from the membrane as a $90-95-k D a$ protein. Both meprin $\alpha$ and meprin $\beta$ form disulfide-bonded dimers. Meprin $\alpha$ may be retained at the cell surface through covalent association with transmembrane meprin $\beta$ via disulfide bonds. Meprin $\alpha$ associates into multimeric protein complexes via non-covalent interactions (Becker et al., 2003; Bertenshaw et al., 2003). 
We analysed the expression of meprin in inflamed mucosa of untreated coeliac disease patients using Western blotting and probing with polyclonal antibodies generated in our laboratory and previously characterised (Grünberg et al., 1993; Lottaz et al., 1999a). The analysis of human clinical specimens was approved by the Hackney and District Health Authority (London, UK) and the Ethics Committee of the Medical Faculty, University of Bern (Bern, Switzerland). Variable levels of the precursor and mature forms of meprin, exhibiting apparent molecular masses between 80 and $110 \mathrm{kDa}$, were detected in protein extracts of small intestinal biopsies of control mucosa, as well as in active coeliac disease (Figure 1A). Accordingly, biopsies of coeliac disease patients, which were cultured in the presence of a peptic tryptic digest of gliadin, retained significant meprin levels (Figure 1B). The significant expression in coeliac disease was not expected, as differentiated enterocytes, which constitute the main expression site in normal mucosa (Sterchi et al., 1988b; Lottaz et al., 1999a), are diminished in the intestinal mucosa in active coeliac disease.

Organ cultures of human foetal gut have been used as a model to demonstrate the crucial role of T-cells and MMPs in the tissue-damaging immune response in the gut (MacDonald and Spencer, 1988; Pender et al., 1997; MacDonald et al., 1999; Monteleone et al., 1999, 2001b). We therefore analysed meprin in the foetal gut system, using well-established procedures that promote T-cell activation and mucosal degradation. Organ cultures were treated with either pokeweed mitogen, or a combination of anti-CD3 antibodies and interferon- $\alpha$ (Figure 2). The latter stimulus was chosen because of enhanced expression of interferon- $\alpha$ in coeliac disease (Monteleone et al., 2001a). Meprin $\alpha$ was mostly secreted from cultured explants and accumulated in the supernatant, whereas only small amounts of cell-associated precursor forms were detected in tissue. The molecular species of meprin $\alpha$ in foetal gut displayed the expected apparent molecular masses of the precursor and mature forms in tissue and supernatant, respectively, and corresponded to those found in meprin $\alpha$-transfected control cells. In contrast to the mature mucosa of the human small intestine, meprin $\beta$ was not significantly expressed in foetal organ cultures. In this respect, the foetal gut resembles the colon in the adult, where meprin $\beta$ is not expressed and meprin $\alpha$ is secreted (Lottaz et al., 1999a). Secretion of meprin $\alpha$ in the absence of meprin $\beta$ has been described previously in cell culture systems (Grünberg et al., 1993; Eldering et al., 1997; Lottaz et al., 1999a) and meprin $\beta$ knockout animals (Norman et al., 2003). The predominant presence of meprin $\alpha$ protein in the human foetal gut points to independent regulation of meprin $\alpha$ and $\beta$ during development and maturation of the intestine. A similarly independent regulation of both subunits has previously been described in postnatal development in rats (Henning et al., 1999). Moreover, Caco-2 cells, human colon carcinoma cells that constitutively express meprin $\alpha$ but not meprin $\beta$, also display a foetal gene expression pattern (Zweibaum et al., 1984; Lottaz et al., 1999b).

Pokeweed mitogen did not alter the expression of meprin $\alpha$ in the foetal gut, nor did it induce meprin $\beta$ (Figure 2A). Neither anti-CD3 nor interferon- $\alpha$ alone or together affected secretion of meprin $\alpha$ (Figure 2B). Thus, meprin was not changed upon T-cell stimulation in the foetal gut system. The foetal gut system has limitations as a model of mucosal inflammation, and the foetal and adult mucosal immune system display marked differences (Spencer et al., 1986). However, injury to epithelial cells is a common hallmark of the inflammatory response in foetal gut, as well as in coeliac disease. As the main expression site of meprin in healthy mucosa is the epithelium (Lottaz et al., 1999a), we hypothesised that inflammation would reduce meprin expression. This hypothesis was disproved, as demonstrated by both the foetal gut system and analysis of intestinal mucosa from coeliac disease patients, which both showed sustained expression of meprin during inflammation.

To identify the cellular source of meprin, in situ hybridisation was performed on tissue sections from coeliac disease patients and normal controls. In mucosal biopsies of control patients, meprin $\alpha$ and $\beta$ mRNAs were
A

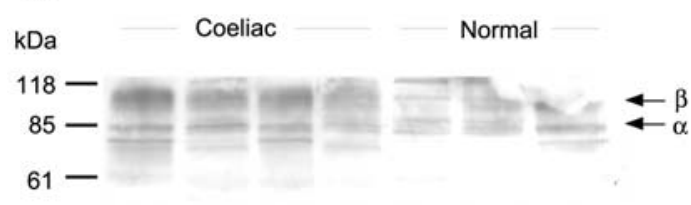

B

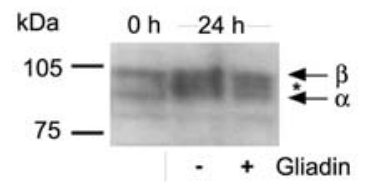

Figure 1 Meprin expression in inflamed small intestinal mucosa of untreated coeliac disease patients and in normal control mucosa. Biopsy specimens were collected during upper endoscopy from the duodenum of four untreated coeliac disease patients, and three control individuals without coeliac disease who displayed normal mucosal histology. Diagnosis was made according to established morphological criteria using haematoxylin-eosin-stained and anti-CD3-labelled tissue sections (Dunnill and Whitehead, 1972; Marsh, 1992). Protein extracts were prepared from tissue homogenates in 1\% Nonidet $\mathrm{P}-40,1 \%$ deoxycholic acid in $25 \mathrm{~mm}$ Tris- $\mathrm{HCl}, 50 \mathrm{~mm}$ $\mathrm{NaCl}, \mathrm{pH} 8.0$, and $150 \mu \mathrm{g}$ of total protein from each sample was separated using 7.5\% SDS-PAGE under reducing conditions. Meprin was detected with anti-human meprin $\alpha / \beta$ cross-reactive polyclonal antibodies on Western blots using enhanced chemiluminescence (Amersham Biosciences, Little Chalfont, UK). (A) Meprin $\alpha$ and $\beta$ in untreated coeliac disease patients compared to normal controls. (B) Representative example of an organ culture experiment with tissue explants from an untreated coeliac disease patient. Equally sized tissue pieces of a biopsy were analysed immediately, or after a 24-h culture period in the presence or absence of $1 \mathrm{mg} / \mathrm{ml}$ of a peptic tryptic digest of gliadin (Sigma Chemical Co., St. Louis, MO, USA) (Fais et al., 1992). Meprin was expressed irrespective of gliadin treatment. Multiple bands (83-103 kDa) are detected, corresponding to differentially glycoslyated forms and to precursor and proteolytically processed mature proteins (Sterchi et al., 1988a). Arrows indicate mature meprin $\alpha$ and $\beta$. The asterisk indicates an additional form present in some biopsies. 

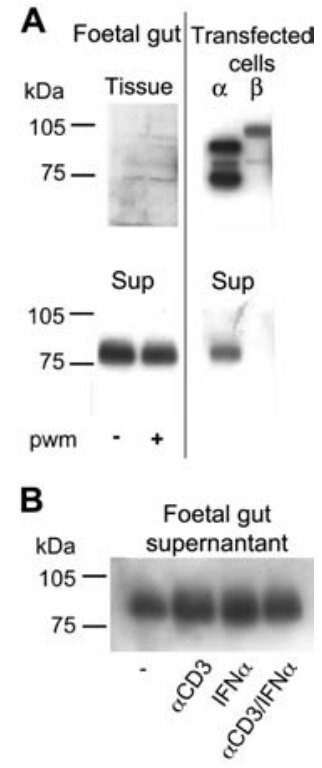

Figure 2 Expression of meprin $\alpha$ in the human foetal gut model of T-cell-mediated mucosal inflammation.

Second-trimester human foetal small intestine (15-16 weeks of gestation) was obtained within $2 \mathrm{~h}$ of surgical termination from the Medical Research Council Tissue Bank, Hammersmith Hospital (London, UK), and Homerton Hospital (London, UK). Foetal gut organ culture in serum-free medium was performed as previously described (MacDonald and Spencer, 1988; Lionetti et al., 1993). Tissue protein extracts (tissue) and organ culture supernatants (sup) were analysed on Western blots. Experiments were carried out at least three times, with representative samples shown. (A) Human foetal gut explants were organ-cultured during 4 days in the presence of the polyclonal T-cell activator pokeweed mitogen (10 $\mu \mathrm{g} / \mathrm{ml}$, Sigma Chemical Co., Poole, UK). As a control, protein extracts and culture supernatants (sup) from meprin $\alpha$ - and meprin $\beta$-transfected Madin Darby canine kidney (MDCK) cells are also shown (Eldering et al., 1997). Multiple forms were detected in cell lysates, corresponding to precursors and proteolytically processed forms, as previously described (Grünberg et al., 1993; Eldering et al., 1997; Pischitzis et al., 1999). Meprin $\alpha$ is constitutively expressed in foetal gut organ cultures and accumulates in culture supernatants. Mature meprin $\alpha$ was secreted from tissue explants similar to meprin $\alpha$ transfected cells. Molecular forms of meprin $\alpha$ in the foetal gut corresponded to meprin $\alpha$-transfected cells. In the foetal gut, tissue-associated forms were detectable only after extended exposure of the blot, whereas mature soluble meprin $\alpha$ was abundantly present in the supernatant, indicating efficient processing and secretion of the protease. Pokeweed mitogen treatment did not change this pattern. Meprin $\beta$, which accumulates at the plasma membrane in transfected cells, was hardly detectable in foetal gut tissue, and was not upregulated by pokeweed mitogen. (B) Foetal gut explants were incubated with anti-CD3 monoclonal antibody (OKT3 supernatant, $5 \%$ final dilution) and $200 \mathrm{IU} / \mathrm{ml} \mathrm{IFN- \alpha 2b}$ (National Institute of Biological Standards and Control, Potters Bar, UK) alone, or simultaneously with both molecules to promote synergistic T-cell activation (Monteleone et al., 2001b). Meprin $\alpha$ in cell culture supernatants was analysed by Western blotting. Meprin $\alpha$ secretion was not visibly affected in anti-CD3- and/or IFN- $\alpha$-treated organ cultures.

predominantly expressed in epithelial cells lining the villi and crypts (Figure 3A, C). In contrast, meprin $\alpha$ - and $\beta$ positive cells were abundantly present within the dense population of macrophages and lymphocytes in the lamina propria in untreated patients with active coeliac disease (Figure 3B, D). In treated patients and healthy
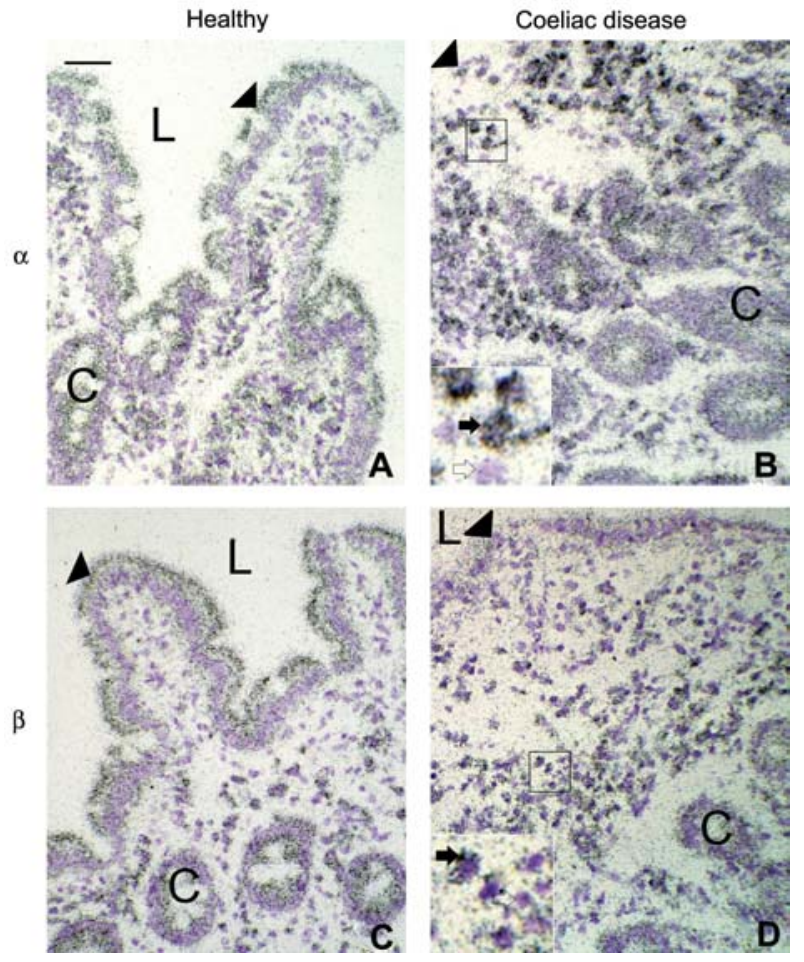

Figure 3 Lamina propria leukocytes expressing meprin $\alpha$ and meprin $\beta$ mRNA are present at higher abundance in the small intestinal mucosa in coeliac disease.

In situ hybridisation (ISH) of sections from formaldehyde-fixed and paraffin-embedded tissues was performed with [ $\left.{ }^{35} \mathrm{~S}\right]-\mathrm{CTP}$ labelled meprin $\alpha$ - and meprin $\beta$-specific RNA probes (Lottaz et al., 1999a). Samples from 20 untreated coeliac disease patients exhibiting partial or complete mucosal atrophy were analysed in comparison with 11 samples showing normal duodenal histology (eight treated coeliac disease patients and three healthy controls not diagnosed with coeliac disease). Representative examples are shown of an untreated coeliac disease patient exhibiting mucosal atrophy and a dense infiltrate of lamina propria leukocytes (B, D) and a healthy control (A, C). (A, B) ISH for meprin $\alpha$. (C, D) ISH for meprin $\beta$. In healthy mucosa, meprin $\alpha$ and meprin $\beta$ mRNAs are predominantly detected in epithelial cells in crypts and along the villus. A few lamina propria leukocytes also express meprin. In coeliac disease, meprin $\alpha$ - and $\beta$ positive lamina propria leukocytes are more abundant, whereas expression in epithelial cells at the mucosal surface is low (arrowheads). L, lumen of the gut; C, crypt. Insets: enlarged area depicting meprin-positive (filled arrow) and -negative cells (open arrow). Counterstain, nuclear fast red. Original objective magnification, $20 \times$. The scale bar represents $50 \mu \mathrm{m}$.

controls, the relative number of meprin $\alpha$ - and $\beta$-positive cells in the lamina propria was below $10 \%$. In contrast, in untreated coeliac disease patients, up to $35 \%$ and $38 \%$ of lamina propria cells expressed meprin $\alpha$ and meprin $\beta$, respectively, and all but two patients had at least $10 \%$ meprin-positive lamina propria cells. The morphology of nuclei in meprin-positive cells was in accordance with lymphocytes and macrophages (Figure 3, insets). We performed CD3 staining of serial sections of coeliac disease tissue adjacent to the sections used for in situ hybridisation. The pattern of CD3-positive and meprin-positive cells differed significantly, suggesting that only a portion of the meprin-positive cells might be T-cells and that additional cell types contribute to meprin expression (data not shown). We did not succeed in iso- 
lating enough lamina propria cells from single coeliac disease biopsies to characterise the meprin-expressing cell populations in more detail using cell sorting and RT-PCR. However, we previously detected meprin $\alpha$ and meprin $\beta$ in a subset of CD45-positive lamina propria leukocytes isolated from surgical specimens of the normal human ileum (Lottaz et al., 1999a). Meprin $\beta$ was also detected in leukocytes from mesenteric lymph nodes, as well as in lamina propria macrophages in mice (Crisman et al., 2004). In contrast to the lamina propria, epithelial meprin mRNA at the mucosal surface was reduced in coeliac disease compared to control mucosa. Therefore, the cellular localisation for meprin shifts from the epithelium in healthy mucosa to the lamina propria in coeliac disease. This explains the lack of major changes in total expression levels on Western blots. This may not be a general feature of mucosal inflammation in the small intestine. Preliminary data indicate that, similarly to healthy mucosa, meprin was expressed predominantly in epithelial cells in inflamed mucosa of Crohn's disease patients (unpublished data). The redistribution of meprin expression from the epithelium to the lamina propria completely changes the substrate repertoire for meprin: whereas the substrates are normally proteins present in the lumen, meprin in coeliac disease has access to the extracellular matrix, growth factors, chemokines and cytokines in the lamina propria, thereby shaping the inflammatory response.

Meprin $\alpha$ and meprin $\beta$ display different substrate specificities and prefer different cleavage sites. Although both enzymes accommodate a range of different amino acids, there are some preferences, in particular at $\mathrm{P}^{\prime}$ positions (Bertenshaw et al., 2001). Using a dodecamer peptide library, meprin $\alpha$ was found to prefer serine at $\mathrm{P}^{\prime}$ ' and proline at $\mathrm{P} 2$ ' and $\mathrm{P}^{\prime}$ positions, whereas meprin $\beta$ preferentially cleaved at sequences containing acidic residues (aspartate and glutamate) at $\mathrm{P} 1^{\prime}$ and $\mathrm{P} 2$ ' positions, and proline at $\mathrm{P}^{\prime}$. Proline at $\mathrm{P} 1^{\prime}$ was not tolerated. Although the preference for these residues is not exclusive, we speculate that gluten-derived peptides, which are the causative agents in coeliac disease and contain sequences matching the preferences mentioned, are substrates for meprin. Meprin $\beta$ has recently been shown to activate pro-IL-1 $\beta$ in vitro (Herzog et al., 2005), a cytokine that is expressed in coeliac disease (Lahat et al., 1999). Meprin also cleaves components of the basement membrane in vitro, such as laminin 1 and 5, nidogen and collagen IV (Kaushal et al., 1994; Walker et al., 1998; Köhler et al., 2000). The latter activity implicates meprin in cell migration through the basement membrane, a hypothesis that is supported by the observation that leukocytes isolated from mesenteric lymph nodes of meprin $\beta$-deficient mice displayed reduced migratory capacity through Matrigel (Crisman et al., 2004). Transmigration through the basement membrane is particularly important for intraepithelial lymphocytes, which are present in increased numbers in coeliac disease (Marsh, 1992; Halstensen and Brandtzaeg, 1993; Jabri et al., 2000).

In summary, we observed a relocalisation of meprin expression from the epithelial cell layer to a mixed population of lymphocytes in the lamina propria in coeliac disease. In the normal small intestine, the bulk of the pro- tease is expressed in enterocytes, targeted to the brush border membrane and partially secreted into the gut lumen, thereby encountering luminal substrates. In contrast, in situ hybridisation experiments presented here show that gluten-induced inflammation in the small intestinal mucosa of coeliac disease patients is accompanied by the predominant expression of meprin $\alpha$ and $\beta$ in lamina propria leukocytes, concomitantly with reduced expression in epithelial cells, thus leading to the accumulation of meprin beneath the epithelial cell layer. Our results highlight the importance of detailed information on the temporal and spatial expression of a given protease in a specific biological context.

We identified meprin as a player within the protease network in coeliac disease. The pathogenetic implications of increased meprin expression in the lamina propria remain to be elucidated, as well as the regulation of meprin in leukocytes. However, the in vitro activity profile of meprin suggests that it is involved in modulation of the inflammatory response at multiple levels. It remains to be seen whether meprin aggravates or dampens inflammation overall. For this purpose, use of meprin-deficient mice in animal models of mucosal inflammation may prove very helpful (Crisman et al., 2004). Ultimately, determination of the biological function of meprin in the intestinal mucosa depends on identification of the relevant substrates in the gut lumen and within the lamina propria.

\section{Acknowledgements}

The authors thank Riccardo Troncone and Virginia Salvati for providing gliadin-treated organ cultures, and Sylvia Pender for providing additional samples of foetal gut organ culture experiments. This study was supported by the Swiss National Foundation and the Royal Society (SNF/Royal Society European exchange fellowship to D.L., SNF grants \#3200-052736 and 3100A0-100772 to E.S.).

\section{References}

Becker, C., Kruse, M.N., Slotty, K.A., Köhler, D., Harris, J.R., Rösmann, S., Sterchi, E.E., and Stöcker, W. (2003). Differences in the activation mechanism between the $\alpha$ and $\beta$ subunits of human meprin. Biol. Chem. 384, 825-831.

Bertenshaw, G.P., Turk, B.E., Hubbard, S.J., Matters, G.L., Bylander, J.E., Crisman, J.M., Cantley, L.C., and Bond, J.S. (2001). Marked differences between metalloproteases meprin $A$ and $B$ in substrate and peptide bond specificity. J. Biol. Chem. 276, 13248-13255.

Bertenshaw, G.P., Norcum, M.T., and Bond, J.S. (2003). Structure of homo- and hetero-oligomeric meprin metalloproteases. Dimers, tetramers, and high molecular mass multimers. J. Biol. Chem. 278, 2522-2532.

Crisman, J.M., Zhang, B., Norman, L.P., and Bond, J.S. (2004). Deletion of the mouse meprin beta metalloprotease gene diminishes the ability of leukocytes to disseminate through extracellular matrix. J. Immunol. 172, 4510-4519.

Daum, S., Bauer, U., Foss, H.D., Schuppan, D., Stein, H., Riecken, E.O., and Ullrich, R. (1999). Increased expression of mRNA for matrix metalloproteinases- 1 and -3 and tissue inhibitor of metalloproteinases- 1 in intestinal biopsy specimens from patients with coeliac disease. Gut 44, 17-25. 
Dumermuth, E., Sterchi, E.E., Jiang, W.P., Wolz, R.L., Bond, J.S., Flannery, A.V., and Beynon, R.J. (1991). The astacin family of metalloendopeptidases. J. Biol. Chem. 266, 21381-21385.

Dunnill, M.S. and Whitehead, R. (1972). A method for the quantitation of small intestinal biopsy specimens. J. Clin. Pathol. 25, 243-246.

Eldering, J.A., Grünberg, J., Hahn, D., Croes, H.J., Fransen, J.A., and Sterchi, E.E. (1997). Polarised expression of human intestinal $N$-benzoyl-L-tyrosyl- $p$-aminobenzoic acid hydrolase (human meprin) $\alpha$ and $\beta$ subunits in Madin-Darby canine kidney cells. Eur. J. Biochem. 247, 920-932.

Fais, S., Maiuri, L., Pallone, F., De Vincenzi, M., De Ritis, G., Troncone, R., and Auricchio, S. (1992). Gliadin induced changes in the expression of MHC-class II antigens by human small intestinal epithelium. Organ culture studies with coeliac disease mucosa. Gut 33, 472-475.

Grünberg, J., Dumermuth, E., Eldering, J.A., and Sterchi, E.E. (1993). Expression of the $\alpha$ subunit of PABA peptide hydrolase (EC 3.4.24.18) in MDCK cells. Synthesis and secretion of an enzymatically inactive homodimer. FEBS Lett. 335, 376-379.

Halstensen, T.S. and Brandtzaeg, P. (1993). Activated T lymphocytes in the celiac lesion: non-proliferative activation (CD25) of $\mathrm{CD}^{+} \alpha / \beta$ cells in the lamina propria but proliferation (Ki67) of $\alpha / \beta$ and $\gamma / \delta$ cells in the epithelium. Eur. J. Immunol. 23, 505-510.

Henning, S.J., Oesterreicher, T.J., Osterholm, D.E., Lottaz, D., Hahn, D., and Sterchi, E.E. (1999). Meprin mRNA in rat intestine during normal and glucocorticoid-induced maturation: divergent patterns of expression of $\alpha$ and $\beta$ subunits. FEBS Lett. 462, 368-372.

Herzog, C., Kaushal, G.P., and Haun, R.S. (2005). Generation of biologically active interleukin- $1 \beta$ by meprin B. Cytokine 31 , 394-403.

Jabri, B., de Serre, N.P., Cellier, C., Evans, K., Gache, C., Carvalho, C., Mougenot, J.F., Allez, M., Jian, R., Desreumaux, P., et al. (2000). Selective expansion of intraepithelial lymphocytes expressing the HLA-E-specific natural killer receptor CD94 in celiac disease. Gastroenterology 118, 867-879.

Kaushal, G.P., Walker, P.D., and Shah, S.V. (1994). An old enzyme with a new function: purification and characterization of a distinct matrix-degrading metalloproteinase in rat kidney cortex and its identification as meprin. J. Cell Biol. 126, 1319-1327.

Koning, F. (2005). Celiac disease: caught between a rock and a hard place. Gastroenterology 129, 1294-1301.

Köhler, D., Kruse, M., Stöcker, W., and Sterchi, E.E. (2000). Heterologously overexpressed, affinity-purified human meprin $\alpha$ is functionally active and cleaves components of the basement membrane in vitro. FEBS Lett. 465, 2-7.

Lahat, N., Shapiro, S., Karban, A., Gerstein, R., Kinarty, A., and Lerner, A. (1999). Cytokine profile in coeliac disease. Scand. J. Immunol. 49, 441-446.

Lionetti, P., Breese, E., Braegger, C.P., Murch, S.H., Taylor, J., and MacDonald, T.T. (1993). T-Cell activation can induce either mucosal destruction or adaptation in cultured human fetal small intestine. Gastroenterology 105, 373-381.

Lottaz, D., Hahn, D., Müller, S., Müller, C., and Sterchi, E.E. (1999a). Secretion of human meprin from intestinal epithelial cells depends on differential expression of the $\alpha$ and $\beta$ subunits. Eur. J. Biochem. 259, 496-504.

Lottaz, D., Maurer, C.A., Hahn, D., Büchler, M.W., and Sterchi, E.E. (1999b). Nonpolarized secretion of human meprin $\alpha$ in colorectal cancer generates an increased proteolytic potential in the stroma. Cancer Res 59, 1127-1133.

MacDonald, T.T. and Spencer, J. (1988). Evidence that activated mucosal $\mathrm{T}$ cells play a role in the pathogenesis of enteropathy in human small intestine. J. Exp. Med. 167, 1341-1349.
MacDonald, T.T., Bajaj-Elliott, M., and Pender, S.L. (1999). T cells orchestrate intestinal mucosal shape and integrity. Immunol. Today 20, 505-510.

Marsh, M.N. (1992). Gluten, major histocompatibility complex, and the small intestine. A molecular and immunobiologic approach to the spectrum of gluten sensitivity ('celiac sprue'). Gastroenterology 102, 330-354.

Monteleone, G., MacDonald, T.T., Wathen, N.C., Pallone, F., and Pender, S.L. (1999). Enhancing lamina propria Th1 cell responses with interleukin 12 produces severe tissue injury. Gastroenterology 117, 1069-1077.

Monteleone, G., Pender, S.L., Alstead, E., Hauer, A.C., Lionetti, P., McKenzie, C., and MacDonald, T.T. (2001a). Role of interferon $\alpha$ in promoting $T$ helper cell type 1 responses in the small intestine in coeliac disease. Gut 48, 425-429.

Monteleone, G., Pender, S.L., Wathen, N.C., and MacDonald, T.T. (2001b). Interferon- $\alpha$ drives T cell-mediated immunopathology in the intestine. Eur. J. Immunol. 31, 2247-2255.

Norman, L.P., Jiang, W., Han, X., Saunders, T.L., and Bond, J.S. (2003). Targeted disruption of the meprin $\beta$ gene in mice leads to underrepresentation of knockout mice and changes in renal gene expression profiles. Mol. Cell. Biol. 23, 12211230.

Pender, S.L., Tickle, S.P., Docherty, A.J., Howie, D., Wathen, N.C., and MacDonald, T.T. (1997). A major role for matrix metalloproteinases in T cell injury in the gut. J. Immunol. 158, 1582-1590.

Pischitzis, A., Hahn, D., Leuenberger, B., and Sterchi, E.E. (1999). N-Benzoyl-L-tyrosyl-p-aminobenzoic acid hydrolase $\beta$ (human meprin $\beta$ ). A 13-amino-acid sequence is required for proteolytic processing and subsequent secretion. Eur. J. Biochem. 261, 421-429.

Salmela, M.T., Pender, S.L., Reunala, T., MacDonald, T., and Saarialho-Kere, U. (2001). Parallel expression of macrophage metalloelastase (MMP-12) in duodenal and skin lesions of patients with dermatitis herpetiformis. Gut 48, 496-502.

Shan, L., Molberg, O., Parrot, I., Hausch, F., Filiz, F., Gray, G.M., Sollid, L.M., and Khosla, C. (2002). Structural basis for gluten intolerance in celiac sprue. Science 297, 2275-2279.

Shan, L., Qiao, S.W., Arentz-Hansen, H., Molberg, O., Gray, G.M., Sollid, L.M., and Khosla, C. (2005). Identification and analysis of multivalent proteolytically resistant peptides from gluten: implications for celiac sprue. J. Proteome Res. 4, 1732-1741.

Sollid, L.M. (2002). Coeliac disease: dissecting a complex inflammatory disorder. Nat. Rev. Immunol. 2, 647-655.

Spencer, J., MacDonald, T.T., Finn, T., and Isaacson, P.G. (1986). The development of gut associated lymphoid tissue in the terminal ileum of fetal human intestine. Clin. Exp. Immunol. 64, 536-543.

Sterchi, E.E., Naim, H.Y., and Lentze, M.J. (1988a). Biosynthesis of $N$-benzoyl-L-tyrosyl- $p$-aminobenzoic acid hydrolase: disulfide-linked dimers are formed at the site of synthesis in the rough endoplasmic reticulum. Arch. Biochem. Biophys. 265, 119-127.

Sterchi, E.E., Naim, H.Y., Lentze, M.J., Hauri, H.P., and Fransen, J.A. (1988b). $\quad N$-Benzoyl-L-tyrosyl- $p$-aminobenzoic acid hydrolase: a metalloendopeptidase of the human intestinal microvillus membrane which degrades biologically active peptides. Arch. Biochem. Biophys. 265, 105-118.

Walker, P.D., Kaushal, G.P., and Shah, S.V. (1998). Meprin A, the major matrix degrading enzyme in renal tubules, produces a novel nidogen fragment in vitro and in vivo. Kidney Int. 53, 1673-1680.

Zweibaum, A., Hauri, H.P., Sterchi, E., Chantret, I., Haffen, K., Bamat, J., and Sordat, B. (1984). Immunohistological evidence, obtained with monoclonal antibodies, of small intestinal brush border hydrolases in human colon cancers and foetal colons. Int. J. Cancer 34, 591-598.

Received April 13, 2006; accepted November 6, 2006 